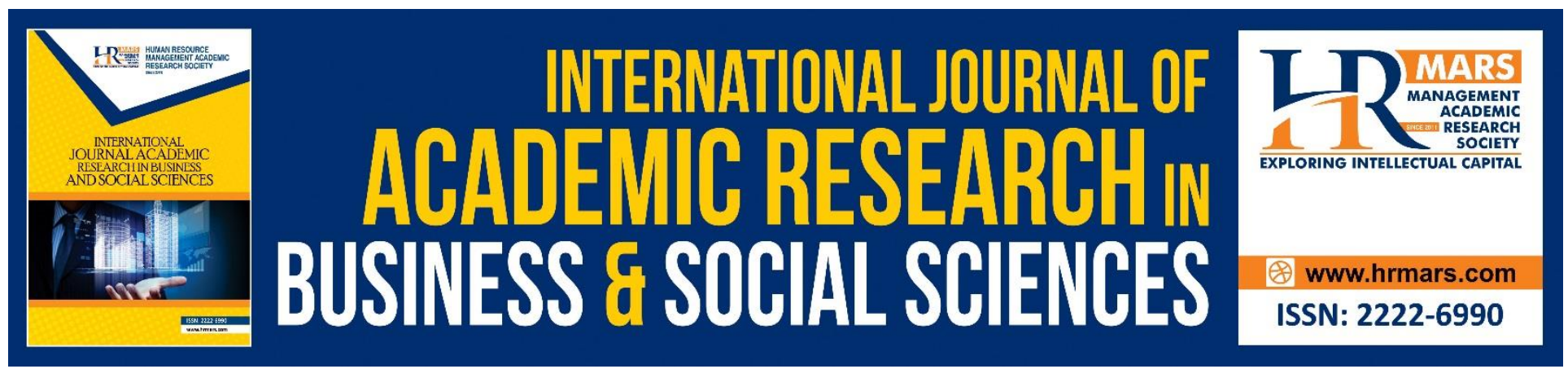

\title{
Determinants of Health Investment in Nigeria: A Case of Infant Mortality (2000-2014)
}

Yemi Meroyi

To Link this Article: http://dx.doi.org/10.6007/IJARBSS/v8-i9/4666

DOI: $\quad 10.6007 /$ IJARBSS/v8-i9/4666

Received: 09 August 2018, Revised: 12 Sept 2018, Accepted: 29 Sept 2018

Published Online: 15 October 2018

In-Text Citation: (Meroyi, 2018)

To Cite this Article: Meroyi, Y. (2018). Determinants of Health Investment in Nigeria: A Case of Infant Mortality (2000-2014). International Journal of Academic Research in Business and Social Sciences, 8(9), 935-949.

Copyright: (C) 2018 The Author(s)

Published by Human Resource Management Academic Research Society (www.hrmars.com)

This article is published under the Creative Commons Attribution (CC BY 4.0) license. Anyone may reproduce, distribute, translate and create derivative works of this article (for both commercial and non-commercial purposes), subject to full attribution to the original publication and authors. The full terms of this license may be seen at: http://creativecommons.org/licences/by/4.0/legalcode

Vol. 8, No. 9, September 2018, Pg. 935 - 949

http://hrmars.com/index.php/pages/detail/IJARBSS

JOURNAL HOMEPAGE

Full Terms \& Conditions of access and use can be found at http://hrmars.com/index.php/pages/detail/publication-ethics 


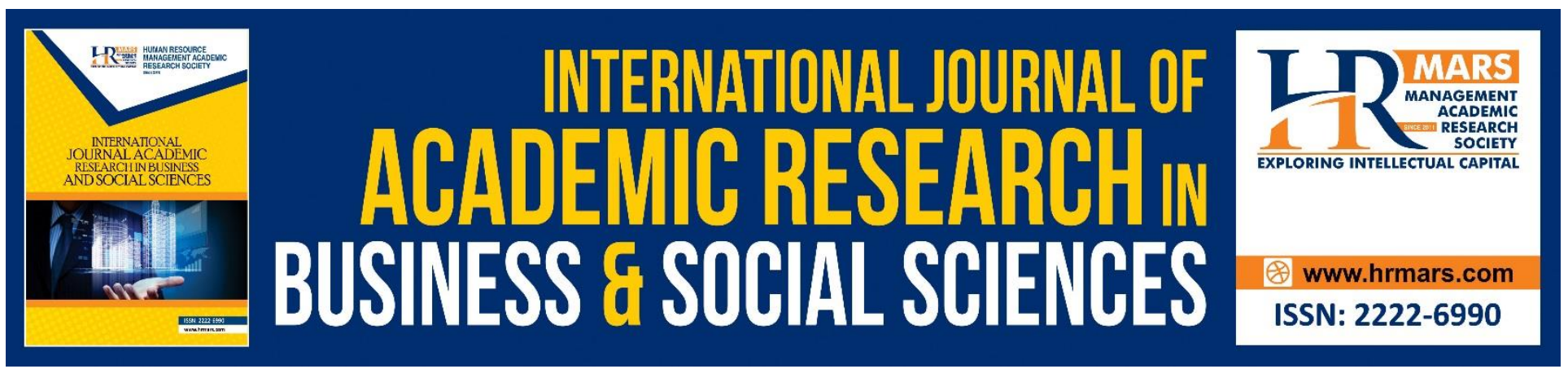

\title{
Determinants of Health Investment in Nigeria: A Case of Infant Mortality (2000-2014)
}

\author{
Yemi Meroyi \\ Department of Social Sciences, Rufus Giwa Polytechnic, Owo, Ondo State, Nigeria \\ Email: meroyem2017@gmail.com
}

\begin{abstract}
The paper examines the determinants of health investment in Nigeria: A case of infant mortality, with the aim of determining the impact of government expenditure, maternal education, and poverty on infant mortality in Nigeria. The study employs descriptive statistics and the Ordinary Least Square econometrics regression method of data analysis, using time series data in Nigeria. Secondary data from WHO, retrieved from indexmundi.com were used for our analysis. The results show that per capita income and maternal education have significant impact on infant mortality in Nigeria. These variables are significant policy variables in achieving lower infant mortality in Nigeria.
\end{abstract}

\section{Introduction}

Health is very vital to human existence. It is one of the most important conditions that guarantee long life. Grossman (1972) argued that good health is required for the production of optimal output based on our education. Therefore, without good health, the scarce resource which is time would not be optimized.

There is increasing empirical evidence that health matters for economic growth and development. Literature on economic growth has clearly showed the role of health in influencing economic performance, at least at the micro level. It is suggested that, all things being equal, healthier workers are more likely to be able to work longer, be generally more productive than their relatively less healthy counterparts, thus, able to secure higher earnings than diseases ridden workers. Babatunde (2012) posited that poor health infrastructure, illness and diseases shorting the working lives of people thereby reducing their life time earnings.

All healthy habits and activities that are deliberately cultivated towards obtaining good health in return are healthy investment, Grossman (1972). Good health guarantees and saves wealth, therefore if health is lost; wealth is also lost because more wealth would be diverted to taking care of health. Hence, health endowment and investment in health determine how long and individual will live, all things being equal. 
Deaths of newborn babies are a major concern in Nigeria because it represents a quarter of the total number of deaths of children under-five.

Despite the high quality and wide spread accessibility of infant intensive care technology all over the world, the rate of infant mortality still remains very high in Nigeria. Infant mortality rate is an important measure of well-being of the infants, children and pregnant women because it is associated with a variety of factors such as maternal health, quality and access to medical care, socioeconomic conditions and public health practices ( Sohler et al., 2003). Infant deaths, which account for half of child mortality, have increased from what they were in 1990.

One explanation of the relationship between parental education and infant health is that greater maternal education translates into greater health care utilization, including formal prenatal visits. The relationship between maternal education and health care services utilization, particularly in developing countries, holds even after controlling for factors that affect both maternal schooling and health care utilization, such as childhood place of residence and ethnicity, as well as socioeconomic variables, such as current residence and husband's education

Besides health care utilization, maternal education can affect infant and child health through several other mechanisms. For example, better educated women have higher income and may "match" with better educated and higher income, husbands (Behrman and Rosenzweig, 2002). Educated women also have greater knowledge of modern health care services and ability to communicate with healthcare providers (Caldwell, 1979; Barrera, 1990). Moreover, education may affect smoking and other health behaviors during pregnancy (Currie and Moretti, 2003). Another channel is through greater female autonomy, which in turn influences health-related decisions and the allocation of resources within the household (Caldwell, 1979; Caldwell et al., 1983). Other possible explanations include greater knowledge about diseases and increased adoption of modern medical practices (Caldwell, 1979; Caldwell, 1990; Barrera, 1990).

Health and income are strongly related across countries and, within countries, across individuals. In the United States, the life expectancy of people in the lowest ventile of the income distribution was about 25\% lower than that of people in the highest ventile in 1980 (Rogot et al., 1992). In developing countries, dozens of studies have found that people with higher incomes have better health status and lower mortality (Gwatkin et al., 2007). It is expected that as countries become richer, life expectancy is also expected to rise, although many other factors are also important in explaining mortality declines. Despite the association between income and health status, the extent to which improvements in income have a causal effect on health status remains controversial. For example, it is said that higher income generally results in access to better parental care, as well as better nutrition for the mother. This finding is not surprising. Infant mortality is concentrated among the poor. If the rich are richer and the average level of income is the same, the poor are poorer. What is surprising, however, is that infant mortality appears to be positively related to the income share of the rich (the upper 5 percent of the income distribution) when the incomes of the poor (the lowest 20 percent) are equalized among countries (Waldmann, 1992). Children, and especially infants, have long been recognized as a group highly vulnerable to bad living conditions.

Government expenditure is the expenses that Government incurs for its own maintenance, society and the overall economy. It is evident that Nigeria over the years spent huge amount of money with a view to improving health system, (Yusuf, 2016). Government in any given society is saddled with 
INTERNATIONAL JOURNAL OF ACADEMIC RESEARCH IN BUSINESS AND SOCIAL SCIENCES

Vol. 8, No. 9, Sept. 2018, E-ISSN: 2222-6990 @ 2018 HRMARS

two basic roles; maintaining law and order as well as providing public goods such as good roads, education, health, defense, and power among other infrastructures (Samuel \& Kabir, 2011).

Health care is a core component of human capital investment, which in turn rising its spending also raises quality of life, prolonged life expectancy, reducing morbidity and mortality rates.

\section{Health Financing in Nigeria}

Nigeria has joined the rest of the world in seeking improvement in the health status of Nigerians as evidenced by the kind of government policies intervention in the development of the health sector to enhance the nation's economic output. In realization of this, successive Nigerian governments have being making serious effort in budgeting allocation to the health sector.

In CBN (2010) the total government expenditure to health as at 1986, 1990, 2000 and 2010 was N360.4M, N558.1M, N18181.8M, and N149269.8M respectively. The capital expenditure also show same continuous increase in trend in 1986, 1990, 2000 and 2010 recorded N18.2M, N157.0, $\mathrm{N} 6569.2 \mathrm{M}$ and $\mathrm{N} 46649.8 \mathrm{M}$ respectively.

According to Imoughele \& Ismaila (2013), the World Bank recommended that $15 \%$ of government budgetary allocation be assigned to the health sector; this has not been achieved by the government, thereby affecting government programs and policies for the development of the sector.

In 2010 alone, Nigeria spent 635 billion Naira on wheat (\$1=150 Naira), 356 billion Naira on importation of rice, and 217 billion Naira on sugar, 97 billion Naira on fish (with all the marine resources, rivers, lakes and creeks which the country is naturally blessed with). This is not fiscally, economically or politically sustainable. The budget that would have gone to health infrastructure is spent on undue foods importation, as nutrition is part of health.

To bring about health care system change, local, state, and federal policymakers need to collaborate more often and more effectively (Atim \& Bhatnagar, 2013). Across states, the level of financial mobilization for health by the public sector varies widely and depends on the roles they play in health care provision. In Northern Nigeria, the public sector provides over $90 \%$ of all health services, in contrast to states in Southern Nigeria, where the private sector provides over $70 \%$ of health services, mostly on a fee-for-service basis (Ichoku \& Okoli, 2015)

Evidence from a Public Expenditure Review of the health sector and National Health Accounts (NHA) suggests that on average, most states spend less than $5 \%$ of their total expenditure on health care. Expenditure from all tiers of government amounts to less than $6 \%$ of total government expenditure and less than $25 \%$ of total health spending in the country. The private sector accounts for the remaining $75 \%$ of health spending, with $90 \%$ of this coming from household out-of-pocket expenditures coupled with the lack of effective risk protection mechanisms such as fee exemptions and health insurance, the cost of seeking health care is prohibitive for many people in Nigeria (Ichoku H \& Okoli C. I, 2015).

Funding for health related expenses has been low primarily because tax-based health financing is limited. Considering the country's current Gross Domestic Product (GDP) of about US\$305 billion, an increase of tax revenue to $15 \%$ of the GDP will result in about US\$21 billion. An allocation of $10 \%$ of this additional income would result in US\$2.1 billion for the health sector. Such re-constitution of revenue collection can represent a great leap forward for the health sector, Ichoku $\mathrm{H} \& \mathrm{Okoli} \mathrm{Cl}$ (2012). 
Usoroh (2012) submitted that increased development aid grants and debt relief have been used to launch the National Health Insurance Scheme (NHIS). The 2014 National Health Act in Nigeria (NHAct) aims to services and use capitation and fee-for-service to pay providers for primary, and secondary and tertiary care services rendered, respectively.

Out-of-pocket expenditures constitute nearly $90 \%$ of the total private health spending, placing a significant burden on households.

Onwujekwe, Hanson, \& Uzochukwu (2012) studies from Southeast and Southwest Nigeria show that $23 \%$ and $11 \%$ of all households sampled, respectively, experienced catastrophic payments for health care. This estimate was higher among those enrolled in health insurance in the poorest households and in rural dwellings - and highest among those not enrolled. (llesanmi, Adebiyi, \& Fatiregun, 2014). Among those in the richest quintile in Southeast Nigeria, only $8 \%$ of households experienced catastrophic costs.

\section{Statement of Research Problem}

The problem of inadequate funding as mentioned above has contributed in no small measure to the incidence of infant mortality rate in Nigeria. This is because the vast majority of newborn deaths take place in developing countries (including Nigeria) where access to health care is low. Most of these newborns die at home, without trained care that could greatly increase their chances for survival. Skilled or trained health care during pregnancy, childbirth and in the postnatal (immediately following birth) period prevents complications for mother and newborn, and allow for early detection and management of problems.

This has made infant mortality a perennial global social problem for a very long time. In the developed countries, the governments have succeeded in decreasing this phenomenon to remarkable levels through implementing health policies which improves children health care and hence increasing survival rate of the infants. In the developing countries, such as Nigeria, though the mortality rates are decreasing, they are still high with about 71.20 deaths per 1000 live births, world statistics (2016). This situation prompted us to delve into issue of infant mortality by analyzing specifically the impact of poverty measured by per capita income, maternal education and government expenditure on infant mortality, to establish whether there exists a relationship between them. This study aimed at determining the impact of government expenditure, maternal education, and poverty on infant mortality in Nigeria.

This study is conducted on Nigeria and covers the period of 15 years (2000-2014). This is because data within the period under reference is readily available. It also covers the determinants of infant mortality and not on the whole of health investment in Nigeria.

Several studies have been done that focused on the determinants of infant and child mortality within and outside Nigeria. Outside Nigeria, and on socioeconomic status with infant and child mortality, Caldwell (1979) reported on the effects of mother's education on reducing child mortality. He put up a theory that mother's education works through changing feeding and care practices, leading to better health seeking behavior and by changing the traditional familial relationships.

In supporting Caldwell's explanation, (Hobcraft, 1993) explained that education can contribute to child survival by making women more likely to marry and enter motherhood later and have fewer 
INTERNATIONAL JOURNAL OF ACADEMIC RESEARCH IN BUSINESS AND SOCIAL SCIENCES Vol. 8, No. 9, Sept. 2018, E-ISSN: 2222-6990 @ 2018 HRMARS

children, utilize prenatal care and immunize their children. The result also, however, showed mysterious conclusion that effect of maternal education on child survival is weaker in sub-Sahara Africa (Devlieger, 2005).

However, a Tanzania study (Mturi and Curtis 1995) had shown lack of infant and child mortality differentials by such socioeconomic factors as, maternal education partner's education, urban /rural residence, and presence of radio in household. But demographic factors such as short birth interval (less than 2 years) teenage pregnancies ( $<20$ years) and previous child death were all significantly associated with increased infant and child mortality.

In Kenya (Hill et al, 2001) reported an inverse relationship between mother's educational level and economic status (wealth index) and child mortality. While for the relationship between urban/rural residence and child mortality, urban areas showed higher mortality risks than rural, but when adjusted for HIV prevalence, child mortality was lower in urban areas.

Adjusting for a number of socioeconomic factors (Mutunga, 2004) found that child survival was found better for those who were of birth order 2-3, birth interval more than 2 years, not outcomes of multiple births, living in wealthier households, had access to drinking water and better sanitation facilities and users of low polluting fuels as their main source of cooking. Maternal age, maternal education and gender of the child had no significant association with child mortality. Zerai (1996) examined socio-economic and demographic variables in a multi-level framework to determine conditions influencing infant survival in Zimbabwe. He employed Cox regression analysis to the 1988 Zimbabwe DHS data to study socioeconomic determinants of infant mortality. The unique finding was that women's average educational level in their community exerts a greater influence on infant survival than the mother's educational level.

Bicego (1990) applied a three-step procedure using proportional hazards regression to estimates trends and determinants of childhood mortality in Haiti. He used the data from the 1987 mortality, morbidity and services utilization survey (MMUS) in Haiti. Maternal education and low age at birth were found to have marked effects on neonatal survivorship but little effect thereafter.

A study by Zerai's (1996) regarding infant mortality Zimbabwe examined the influence of socioeconomic and demographic factors. With the utilisation of the Zimbabwe 1988

Demographic and Health Survey, a multilevel framework was used to determine the rate of infant survival within the country (Zerai, 1996). This study employed the Cox regression14 multilevel analysis and concluded that education was an important factor in infant mortalityin Zimbabwe.

Hisham et al; (2008) examined socioeconomic determinants of infant mortality in Kenya. They employed the logistic regression model, in testing the magnitude of the significance of each selected variable on the $2003 \mathrm{KDHS}$ data to study socioeconomic determinants of infant mortality. The factors were then rank -ordered according to their overall P-value. Their study did not show the differential impact of the independent variables on infant and child mortality.

Evidence from studies that used data of census and demographic surveillance systems (Bhuiyat, 1991) showed the same mortality differential by maternal education. The only identified counterintuitive result on this association was brought by Adetunji (1995) who had examined the 1986-1987 Ondo state DHS using birth history data from 2635 women aged 15-49. The study showed that infant mortality is higher in those born to mothers with secondary education compared to 
uneducated mothers. He suggested that the lower maternal age at birth and less duration of breastfeeding which were associated with this group of women could be responsible for this finding. Quite a few studies have been done in Nigeria that focused on the determinants of infant mortality. Nwufo, Ebiriekwe, \& Onwuliri (2015) examined risk factors associated with infant mortality in owerri metropolis, imo state, southeastern Nigeria. Pre-tested structured questionnaires were administered to the respondents for data collection, using descriptive statistics and chi square test. They found that Human Immunodeficiency Virus (HIV) infection, malnutrition, alcohol intake, level of mother's education, previous caesarian section), antenatal factors (low birth weight, gestational diabetes, failure to receive tetanus toxoid vaccine, congenital malformation, drinking alcohol, smoking or staying near a smoker, malaria in mother, obesity, feeding habit of a pregnant woman) and post natal factors (overweight of a baby, place of delivery, birth attendant, preterm birth, length of labour, placenta abnormalities, caesarian section, failure to have a wellness baby check, jaundice) were observed to contribute to infant mortality.

Babatunde (1992) researched into Developmental Implications of Early Mortality Factors in Nigeria. This showed that higher parental income and higher density of modem health facilities constitute the combination of factors most likely to bring about sustained reductions in early mortality levels.

Ayenigbara \& Olorunmaye (2012) investigated the causes of infant mortality in Akoko South West Local Government Area of Ondo State. Descriptive survey research design was used and result analysed with simple percentage and chi-square statistics. The finding showed that too frequent pregnancies, age of expectant mother, poor nutrition, poverty and lack of adequate medical care caused infant mortality in Akoko South West Local Government Area of Ondo State

Adetoro \& Amoo (2014) conducted a statistical analysis of child mortality: Evidence from Nigeria. Cross-tabulation and binary logistic regression techniques were employed in the statistical analysis. The result established that education of both parents and occupation of mothers were found statistically significant to reduction in child mortality rate.

Aigbe \& Zannu (2012) examined the differentials in infant and child mortality rates in Nigeria: Evidence from the six geopolitical zones. Data for the study was obtained from the Nigeria Demographic and Health Surveys of 1999 and 2008. The findings of the research showed that there were significant spatial differences in infant mortality rates and under-five mortality rates among the country's geo-political regions in 1999 and 2008 and by rural urban residence.

Looking at the above review, there has not been consensus on the impact of the maternal education, per capita income and government expenditure on infant mortality in Nigeria. While some researchers agreed that increased per capita income, government expenditure and maternal education reduce infant mortality, others found that one or two of the explanatory variables actually impact on the dependent variable. This study therefore is to find out the actual impact of these explanatory variables on infant mortality in Nigeria.

\section{Theoretical Framework}

This study is be based on early works in human capital theory attributed to Becker (1964), Porath (1967) and which was later modernized by Grossman (1972). According to Becker and Proath the stock of knowledge (education) an individual determines his or her level of productivity. They see knowledge as the major determinant of human capital. 
INTERNATIONAL JOURNAL OF ACADEMIC RESEARCH IN BUSINESS AND SOCIAL SCIENCES

$\mathrm{HC}=\mathrm{f}$ (Education)

In his proposition on human capital, Grossman (1972) pointed out that good heath is required for production of optimal output based on our education. To him when good health is lacking, the scarce resource "Time" would not be optimized. The repercussion of this proposition is that although education is needed for production, good health is very vital in harnessing education for optimal production.

Thus, Grossman assertion of the human capital model shows that (1) education matters (2) health implies investment (3) time is an important variable that may become endogenous, and (4) the stock of knowledge is important but different from education in the process of production.

$\mathrm{HC}=\mathrm{f}$ (Knowledge, health stock, education).

In his theory, Grossman assumed a representative agent who has all the necessary information to make optimal choices. The objective of this agent is to maximize utility subject to his budget constraint. Thus the utility function could be given thus:

$\mathrm{U}=\left(\mathrm{Q}, \mathrm{H}_{\mathrm{t}}, \mathrm{Z}_{\mathrm{t}}\right)$

Where $U$ is the utility function, $Q$ is the fraction of health consumed at $t, H_{t}$ is the total stocks of health at $t$ and $Z_{t}$ is the bundle of goods consumed for utility at $t, h$ is the total consumption of health services.

Equation 3 is the utility function stating that utility at time t depends on some choice sets of variable. In the utility function, $\mathrm{Q}, \mathrm{H}_{\mathrm{t}}$, and $\mathrm{Z}_{\mathrm{t}}$ are control variables where $\mathrm{H}_{\mathrm{t}}$ is the solution to the problem of optimal health. $\mathrm{H}$ is the total consumption of health services. It can also be seen as healthy time since the amount of health services consumed would determine the amount of healthy time the agent has to spend. Letter $t$ as a subscript represents the particular time point between birth and death.

Hence $t \in(O, T)$. (4), where $O$ in the relation 4 implies time of birth and $T$ time is time of death. Time of death $(T)$ is a function of healthy time. Hence, $T=f\left(H_{t}\right)$......

An important part of the total current stock of health $\left(H_{t}\right)$ is the initial stock of health $H_{0}$. It is exogenous endowment of health. It is made up of genetic and start-up environment. This is so because given a critical health point, $\mathrm{H}_{(\mathrm{min})}$, that is, a minimum heath requirement for survival, if the total health stock of a given agent is below this, then the agent would die. That is, if $\mathrm{H}_{\mathrm{t}} \leq$ $H_{(\min )}$ will lead to death.

Grossman dynamic model states that future or tomorrow's health is the sum of current heath is the sum of current health and gross investment on health minus depreciation.

Hence, $\mathrm{H}_{\mathrm{t}+1}=\mathrm{H}_{\mathrm{t}}+\mathrm{I}-\delta \mathrm{H}_{\mathrm{t}}$.

(6). Where $\delta$ is depreciation and I is gross investment on health. It should be noted that $\delta$ wears with age. Hence, $\delta=f$ (age).....

Equation 6 above implies that human capital depreciates with age, however, aging can be delayed by investment in heath. It should be noted that when ageing problem is genetic it will be impossible to do something about it. From equation 6 above, the net investment model can be derived thus: $\Delta$ $\mathrm{H}_{\mathrm{t}+1}=\mathrm{I}-\delta \mathrm{H}_{\mathrm{t}}$

Equation 7 says that net health investment is gross investment minus current health depreciation.

The Grossman investment model asserts that all healthy habits and activities that are deliberately cultivated towards obtaining good health in return are health investment. Thus typical health investment model could be $I_{t}=I(M, T H, E)$ where $M$ is the goods that the individual purchases to 
produce good health like medical care. TH is the time spent in producing health such as sleeping time, eating time and exercising time.etc and $E$ is knowledge parameter. Thus when an individual deliberately spend efforts at maximizing this variables, he hope to get $\mathrm{M}$ return in good health subject to age and genetics.

Grossman production model includes the combination of those economic activities that yield good health. To him, the health production model could be specified at $Z_{t}=Z(X, T, E) . Z_{t}$ is bundle of goods consumed for utility, $X$ represents the bundle of goods that contributes to the production of $Z$ which could be land, seeds planted, other capital goods, $T$ is the time spent on producing $Z$. these activities yield output that are consumed by the individuals. In summary, the basic Grossman model is characterized by the utility function, the investment and production functions.

The dynamic form of the model is given as $\mathrm{H}_{t+1}=\mathrm{H}_{t}+\mathrm{I}_{\mathrm{t}}-\delta \mathrm{H}_{\mathrm{t}}$

\section{Model Specification}

The study is carried out to determine the factors that affect investment in health: A case study of infant mortality in Nigeria. Three explanatory variables will be considered. They are poverty, represented with per capita, government expenditure on health and maternal education.

$\mathrm{IFN}=\beta_{0}+\beta_{1} \mathrm{PCl}+\beta_{2} \mathrm{GEXP}+\beta_{3} \mathrm{MEDU}+\mu$

Where IFN represents Infant mortality rate, $\mathrm{PCl}$ represents Per capita income, GEXP represents Government expenditure on health, MEDU represents Maternal Education and $\mu$ is the error term.

\section{Methodology}

The study employs descriptive statistics and the Ordinary Least Square econometrics regression method of data analysis, using time series data in Nigeria. Secondary data from WHO, retrieved from indexmundi.com are used for our analysis.

\section{Presentation and Interpretation of Result}

The variables involved in the analysis are: Infant Mortality (IFN), Per capita income (PCI), Government expenditure (GEXP) and Maternal Education (MEDU).

So, we estimated the equation below:

$\operatorname{InIFN}=\beta_{0}+\beta_{1} \ln \mathrm{PCI}+\beta_{2} \ln \mathrm{EEXP}+\beta_{3} \ln \mathrm{MEDU}+\mu$ 
INTERNATIONAL JOURNAL OF ACADEMIC RESEARCH IN BUSINESS AND SOCIAL SCIENCES Vol. 8, No. 9, Sept. 2018, E-ISSN: 2222-6990 (C) 2018 HRMARS

Source: WHO; Retrieved from indexmundi.com

\begin{tabular}{|l|l|l|l|l|l|}
\hline S/N & Year & $\begin{array}{l}\text { Government } \\
\text { Expenditure }\end{array}$ & Per Capita Income & Education & Infant \\
\hline $\mathbf{1}$ & 2000 & 5.9 & 2351.1 & 22.4 & 576113 \\
\hline $\mathbf{2}$ & 2001 & 4.5 & 2504.9 & 24.5 & 573916 \\
\hline $\mathbf{3}$ & 2002 & 3.7 & 2646.0 & 25.5 & 571094 \\
\hline $\mathbf{4}$ & 2003 & 5.9 & 2938.7 & 30.5 & 566996 \\
\hline $\mathbf{5}$ & 2004 & 8.8 & 3196.9 & 31.0 & 562664 \\
\hline $\mathbf{6}$ & 2005 & 7.3 & 3490.1 & 31.7 & 556383 \\
\hline $\mathbf{7}$ & 2006 & 8.6 & 3792.5 & 30.9 & 549338 \\
\hline $\mathbf{8}$ & 2007 & 7.3 & 4132.5 & 27.7 & 542164 \\
\hline $\mathbf{9}$ & 2008 & 8.6 & 4429.5 & 32.1 & 535507 \\
\hline $\mathbf{1 0}$ & 2009 & 9.2 & 4733.3 & 36.4 & 527491 \\
\hline $\mathbf{1 1}$ & 2010 & 7.6 & 5127.7 & 41.2 & 520546 \\
\hline $\mathbf{1 2}$ & 2011 & 7.4 & 5342.4 & 41.9 & 512630 \\
\hline $\mathbf{1 3}$ & 2012 & 5.7 & 5519.3 & 44.9 & 504984 \\
\hline $\mathbf{1 4}$ & 2013 & 7.4 & 5745.7 & 53.5 & 497623 \\
\hline $\mathbf{1 5}$ & 2014 & 7.4 & 6031.4 & 54.3 & 489949 \\
\hline
\end{tabular}

. reg InINRAN InGEXP InPCI InBDUC

\begin{tabular}{|c|c|c|c|}
\hline Source & SS & df & llurber of obs $=15$ \\
\hline Model & .040459266 & 3.013486422 & Prob $>E=0.0000$ \\
\hline Residual & .00102637 & 11.000093306 & R-squared \\
\hline Total & .041485636 & $14 \quad .00296326$ & Root MSE \\
\hline
\end{tabular}

\begin{tabular}{|c|c|c|c|c|c|}
\hline lniNPAIIT & Coef. & Std. Brr. & t & $P>|t|$ & [95\% Conf. Interval] \\
\hline $\operatorname{lngEXP}$ & .0280785 & .0125037 & 2.25 & 0.046 & .0005581 \\
\hline $\ln$ PCI & -.1296516 & .0235972 & -5.49 & 0.000 & $\begin{array}{ll}-.1815887 & -0777145\end{array}$ \\
\hline $\ln B D C C$ & -.0614319 & .0257738 & $-2,41$ & 0.035 & $-.11749955-0053644$ \\
\hline _cons & 14.43274 & .1075046 & 134.25 & 0.000 & 14.19612 \\
\hline
\end{tabular}

Source: Author's computation

The independent variables explain about $98 \%$ of the variation in the value of the dependent variable. This means that the $\mathrm{R}^{2}$ which is the coefficient of determination is good enough to make informed decisions; the residual giving evidence that other factors apart from the ones enumerated in the models contribute only about $2 \%$ of the variation that occurs in the dependent variable. The F- 
Statistic which shows the overall performance of the model is significant at $5 \%$ showing that the model is brilliant enough to make inferences upon. Even when the $\mathrm{R}^{2}$ was adjusted for degree of freedom, the entire explanatory variables combine still have a relationship with infant mortality. The $\mathrm{t}$-statistic for all the explanatory variables except government expenditure is also significant at $5 \%$ level of significance.

Though there is the limitation of small observation sample, the analysis of the partial contribution of each explanatory variable can still be dependable.

The government expenditure on health (gexp) has a positive coefficient $(0.028)$ in the estimation showing that it is positively related to the dependent variable, it means that a $1 \%$ increase in government expenditure on health increases infant mortality by about $0.028 \%$. This does not follow intuition and theory. This is where the problem is, the impact of government expenditure on health is not statistically significant in the model. This could be as a result of the reliability power of the data. It is expected that there should be significant statistical relationship between government expenditure on health and infant mortality. This calls for further studies.

Maternal education has an inverse relationship with infant mortality. This means that the higher the education level of mothers, the less the death of their babies. This follows intuition and theory. From the result, a $1 \%$ increase in the level of education reduces infant mortality by $-0.061 \%$. High level of education of mothers exposes them to better knowledge and health behaviour, good hygiene and better understanding of first aids applications. Also, an educated pregnant woman is not likely to stay at home during delivery and will not patronise quack doctors, she will also go to the hospital when her baby is sick and will not resort to the use of native herbs etc.

Per capita income is a welfare variable, it used to measure whether an individual is poor or otherwise. Increase in the welfare of people; mother and children especially will reduce infant mortality. The estimation confirms that an inverse relationship exists between per capita income and infant mortality rate. It shows that a $1 \%$ increase in the per capita income will reduce infant mortality by around $-0.061 \%$. This variation is statistically significant at $5 \%$ level. The $p$-value $(-0.122)$ and the confidence interval also reveal that per capita income plays a very significant role in reducing infant mortality. Higher income generally results in access to better prenatal care, as well as better nutrition for mother. So a reliable inference can be drawn from the estimation, as higher income enhances access to better health care services

\section{Summary, Conclusion and Recommendation Summary}

This study sought to determine the impact of government expenditure, per capita income and maternal education on infant mortality in Nigeria covering the period 2000 to 2014. Section A handled the introduction while section $B$ is cantered on review of literature and empirical analysis. Section $C$ focused on the theoretical framework, methodology employed and model specification while section $D$ dealt with presentation and interpretation of data. Finally, section $E$ put forward the summary, conclusion and recommendation. 


\section{Conclusion}

Major contributors to the variation of infant mortality are the per capita income and maternal education. Increased income predisposes an individual to better life and access to better health care facilities which reduce infant mortality. Also, an educated mother will know the right thing to do when her baby is ill. She will not expose her baby to dangerous practices such as the use of dangerous herbs and will not delay visits to the hospital and clinic when her baby is sick. These variables are significant policy variable in achieving lower infant mortality in Nigeria. An increase in per capita income and maternal education reduces infant deaths. When the welfare of mothers and children are enhanced, the welfare of infants is also enhanced, and the incidence of infant mortality will reduce.

\section{Recommendations}

Since an increase in income raises the returns on healthy days, effort must be made by governments and private employers of labour at ensuring that salaries and wages are paid as at when due to enable people to attend to their health when the need arises.

- Deliberate efforts should be made by governments to ensure more female enrolments in school since maternal education reduces infant mortality. It is almost impossible for an unhealthy mother to give birth to a health child. There should be more enlightenment campaigns on the need for pregnant women to visit good hospitals frequently and timely too.

- All forms of delay in seeking care during delivery should be minimised if it cannot be completely minimised. Delay in seeking care during delivery can very fatal to the baby and even the mother

- Government must begin to make effort to undertake free medical care especially the pregnant women and infants to reduce both infant and maternal deaths. Effort must be made by the governments (Federal and States) to increase their budgetary allocation on health.

\section{References}

Yusuf, M. B (2016). An Assessment of the Impact of Government Expenditure on Infrastructures: Evidence from Nigerian Health Sector Performance. European Journal of Business and Management, (8)14: 222-298.

Ichoku, H.E and Okoli, C.I (2015) Fiscal Space for Health Financing in Nigeria. African Journal Health Economics, E Publication ahead of print.

Nwufo Regina, C., Nwaokoro, J. C., Ibe Sally, N. O., Ihenachor, C A., Emerole Chima O. Ebiriekwe, S.C., Onwuliri, V .A. (2015) Science Journal of Public Health, 3(5-1): 64-71.

Ilesanmi , O.S, Adebiyi. A. O, Fatiregun A.O , (2014) National health insurance scheme: how protected are households in Oyo State, Nigeria from catastrophic health expenditure? International Journal of Health Policy and Management, 2(4), 175-180

Adetoro, G.W., AMOO Emmanuel, O. (2014), A Statistical Analysis of Child Mortality: Evidence 
INTERNATIONAL JOURNAL OF ACADEMIC RESEARCH IN BUSINESS AND SOCIAL SCIENCES

Vol. 8, No. 9, Sept. 2018, E-ISSN: 2222-6990 (C) 2018 HRMARS

Fron Nigeria. Journal of Demography and Social Statistics, Obafemi Awolowo University lle Ife, Nigeria (1)1, 110-120.

Imoughele, L.E. and Ismaila, M. (2013). Determinant s of Public Health Care Expenditure in Nigeria: An Error Correction Mechanism Approach; International Journal of Business and Social Science (4)13, pp 220.

Atim, C. \& Bhatnagar, A. (2013). Toward Synergy and Collaboration to Expand the Supply of and Strengthen Primary Health Care in Nigeria's Federal Context, with Special Reference to Ondo State. Universal Health Coverage Studies Series (UNICO) No. 3. The World Bank. Washington DC.

Onwujekwe, O., Hanson, K., Uzochukwu, B. (2012) Examining Inequities in Incidence of

Catastrophic Health Expenditures on Different Healthcare Services and Health Facilities in Nigeria. PLOS ONE 7(7): e40811

Aigbe, G. O., Zannu, A. E. (2012) Differentials in Infant and Child Mortality Rates in Nigeria: Evidence from the Six Geopolitical Zones; International Journal of Humanities And Social Science ISSN 2220-8488 (Print), 2221-0989 (Online)

Ayenigbara, G. O., Olorunmaye, V. B. (2012). Investigating the Causes of Infant Mortality in Akoko South West Local Government Area of Ondo State, Nigeria. Scientific \& Academic Publishing, 2(6): 180-184.

Onwujekwe, O., Hanson, K., and Uzochukwu, B. (2012) 'Examining inequities in incidence of catastrophic health expenditures on different healthcare services and health facilities in Nigeria.', PLoS One, ( 7 ) 740811.

Usoroh, E.E. (2012). Achieving universal health coverage in Nigeria: The National Health Insurance Scheme as a tool. 48th International Course in Health Development. KIT (Royal Tropical Institute). Amsterdam, Netherlands. September 19, 2011-September 7, 2012

Hisham, E. M. and Clifford, O. (2008). Socioeconomic Determinants of Infant Mortality in Kenya "Humanities and social science.

Devlieger, H., G. Mortens and A, Bekaert. (2005). "Social inequalities in prenatal and infant mortality in the northern region of Belgium (the Flanders)" European Journal of Public Health; 15(1): 15-19.

Mutunga, C. J. (2004). "Environmental Determinants of Child Mortality in Kenya”. Kenya Institute for Public Policy Research and Analysis (KIPPRA), Nairobi Kenya. (accessed 21/02/2012).

Sohler, I., Arno, S., Chang, J. S. (2003). Income inequality and infant mortality in New York City. J . Urban. Health, 80:650-657 
INTERNATIONAL JOURNAL OF ACADEMIC RESEARCH IN BUSINESS AND SOCIAL SCIENCES

Vol. 8, No. 9, Sept. 2018, E-ISSN: 2222-6990 (C) 2018 HRMARS

Currie, J. and Moretti, E. (2003). Mother's education and the intergenerational transmission of human capital: Evidence from college openings. The Quarterly Journal of Economics, 118(4):1495-1532

Behrman, J. R. and Rosenzweig, M. R. (2002). Does increasing women's schooling raise the schooling of the next generation? American Economic Review , 92(1):323-334.

Zerai, A. (1996). Preventive health strategies and infant survival in Zimbambwe. African Population studies 11 (1): 120-156

Mturi, A. J., and Curtis, S. L. (1995) The determinants of infant and child mortality in Tanzania". Health Policy Plan; 10:384-394.

Hobcraft, J. (1993) "Women's education, child welfare and child survival: a review of the evidence". Health Transition Review: 3(2): 159-173 Kenya National Bureau of Statistics 12011).

Bhuiyat, A. and Streatfield, K. (1991) “Mothers' and Survival of Female Children in a Rural Area of Bangladesh". Population Studies; 45:253-264

Bicego, G. (1990).Trends, age patterns and determinants of childhood mortality in Haiti. [PhD dissertation]. Baltimore: The Johns Hopkins University.

Barrera, A. (1990). The role of maternal schooling and its interaction with public health programs in child health production. Journal of Development Economics, (32)4:69-91.

UNICEF. The state of the world's children, 1989. Oxford university press, Oxford, N .y., 1989 ).

Flagg, A. (1982) "Inequality of Icome, Illiteracy, and Medical Care as Determinants of Infant Mortality in Developing Countries" Population Studies, XXXII

Caldwell, J. C. (1979), Education as a factor in Mortality Decline: An Examination of Nigeria Data. Population Studies; 33 (3): 395-413

Rogers, G. (1979) "Income and Inequality as Determinants of Mortality: An International Cross Sectional Analysis", Population studies, XXXIII.

Caldwell, J. C. (1979). Education as a Factor in Mortality Decline: An Examination of Nigerian Data. Population Studies , (33)6:395-413

Cox, D. R. (1972). Regression models and life tables. Journal of the Royal Statistical Society Series B (methodological) 34 (2): 187-220. 
INTERNATIONAL JOURNAL OF ACADEMIC RESEARCH IN BUSINESS AND SOCIAL SCIENCES Vol. 8, No. 9, Sept. 2018, E-ISSN: 2222-6990 @ 2018 HRMARS

Michael, G. (1972). The Demand for Health: A Theoretical and Empirical Investigation. Columbia University Press. 